\title{
A Critical Literature Review for Islamic Banks Selection Criteria in Malaysia
}

\author{
Farah Amalina Md Nawi ${ }^{1}$, Ahmad Shukri Yazid ${ }^{1} \&$ Mustafa Omar Mohammed ${ }^{2}$ \\ ${ }^{1}$ Faculty of Business Management \& Accountancy, University Sultan Zainal Abidin, Gong Badak, Kuala \\ Terengganu, Malaysia \\ ${ }^{2}$ International Islamic University, Gombak, Kuala Lumpur, Malaysia \\ Correspondence: Ahmad Shukri Yazid, Faculty of Business Management \& Accountancy, University Sultan \\ Zainal Abidin, Gong Badak, 21300, Kuala Terengganu, Malaysia. E-mail: shukri@unisza.edu.my
}

Received: April 10, 2013

Accepted: May 20, 2013

Online Published: May 24, 2013

doi:10.5539/ibr.v6n6p143

URL: http://dx.doi.org/10.5539/ibr.v6n6p143

\begin{abstract}
Islamic banking initially established to cater for the needs of Muslims customers, as Muslims are obliged to obey the Shari'ah principles (Islamic Jurisprudence) in all aspects of life. However, the number of non-muslims involved in Islamic banking is increasing. In the case of Malaysia, the contributions of non-Muslims towards the development of Islamic banking have been remarkable, as some banks report that more than half of their Islamic financial products is by non-Muslim customers. It is argued that Muslims patronize Islamic banking due to religious consideration however, it is not clear why the non-Muslims patronize Islamic banking. Hence, the study aims to examine critical criteria for Islamic banks selection. The findings from the literature show that there are six main reasons why customers prefer Islamic banking, namely understanding of Islamic banking concept, Shari'ah compliance, religious contradiction, quality and attractiveness of offerings, willingness to deal with Islamic banks and prospect and potentials of Islamic banking.
\end{abstract}

Keywords: Islamic banking, Islamic finance, selection criteria, Malaysia

\section{Introduction}

Islamic banks operate worldwide in over 75 countries mostly in Middle East and Southeast Asia, with Bahrain and Malaysia as the biggest hubs. Islamic banking has established itself as a choice of banking alongside the conventional interest-based banking, and it has been expanding rapidly over the last two decades in both Muslim and non-Muslim countries. As it is expanding from its niche, the Islamic banking industry is becoming a market that could rival the conventional sector in many countries. Dusuki and Abdullah (2006) described Islamic banking as no longer a business entity operated only to fulfill the religious obligations of the Muslim community, but more significantly, it is striving to fulfill the needs and demands of new customers as well (as cited in Wilson, 1995).

The growth of Islamic banking continues to attract and draw the attention of several institutions all over the world. Almost 25 percent of Islamic financial institutions now operate in countries that do not have Muslim majorities, while interest-based banks have opened up "Islamic windows" to attract the growing number of Muslims living in Europe and North America (Pollard \& Samers, 2007). The first attempt of Islamic bank in the Western world represent by the Islamic Finance House, established in Luxembourg in 1978. There is also the Islamic Bank International of Denmark in Copenhagen, and the Islamic Investment Company in Melbourne, Australia. According to Shanmugam, Perumal, and Ridzwa (2004), there was tremendous movement of Islamic banking into Western countries, especially in the United Kingdom, Australia and the United States. Meanwhile, in non-Western countries where Muslims are the minority, such as India, the proliferation of Islamic financial institutions as interest-free savings and loans began during the seventies (Siddiqi, 1988).

Islamic banking in Malaysia has emerged as one of the important components of the overall financial system and contributes to the growth and development of the economy since its establishment in 1983. Malaysia is perhaps the only country with a complete Islamic banking system as it has surpassed other Muslim countries in terms of market infrastructure in the Islamic finance industry. According to Aziz (2006), the Islamic banking industry in Malaysia has been growing in terms of assets at an average rate of 18 percent per annum since 2000. In the first seven months of 2011, Islamic banking assets in Malaysia rose 15 percent to 389.3 billion ringgit (USD $\$ 123$ 
billion), strengthening the country's position as the global hub for Shari'ah-compliant financing (Business Week, 2011). Presently, Malaysia has the most established Shari'ah regulatory and legal infrastructure in the world, and the Islamic capital market now exceeds $\$ 1$ trillion ringgit and is growing as rapidly as the conventional capital market (Ministry of Finance: 2011-2012 Economic Report).

A report by Malaysia International Islamic Financial Centre (2012) stated that there were several factors contributed to the strong growth of Islamic banking in Malaysia. These factors include the continuous products innovation, a wide range of innovative Islamic financial products, a large and diverse pool of Islamic finance talent, diversity of financial institutions, a comprehensive Islamic financial infrastructure as well as adoption of global regulatory, legal and Shari'ah best practice, alongside the unwavering support by the government in providing the impetus for growth of the local Islamic financial services industry. All these factors enabled Malaysia to grow into one of the most dynamic business environments in South East Asia. Currently, there are 27 banking institutions consisting of 9 fully fledged Islamic banks and 18 conventional banking institutions offering Islamic banking products and services under the Islamic Banking Scheme (IBS) (Bank Negara, 2006). The Islamic finance infrastructure is strengthen with the involvement of the Malaysian Central Bank by providing guidelines to institutions to operate IBS in line with Shari'ah principles (Rosly \& Abu Bakar, 2003).

The positive perception of customers especially among non-Muslims towards Islamic banking in Malaysia is far more crucial to be examined, especially due to the fact that Islamic banks have to compete with conventional banks that have long existed in the dual banking system. In its initial years, the response to Islamic banking was mainly from a market segment of Muslims who were concerned about practicing Islamic principles in all spheres including banking whilst notable efforts were made to market the Islamic banking products to the non-Muslims. Apparently, in recent years, non-Muslims have become the major users of Islamic banking products and services. Husin (2008) reported that non-Muslims have gradually become the major users of Islamic banking in Malaysia, indicated by the banks such as the Hong Leong Islamic Bank, Oversea-Chinese Banking Corporation (OCBC) and even the Malaysian Cooperative Bank (Bank Rakyat) have reported a 70 per cent uptake of Islamic financial products by Chinese customers. This indicates the degree of acceptance of Islamic banking among the Chinese community in Malaysia as their choice in banking transactions.

The main aim of this study is to examine several critical factors in selecting Islamic banks. This subject is considered very timely with the development of Islamic banking in this country. Furthermore, there is not much research that has been done in this specific issue, hence the study could add to the existing knowledge in this field. The rest of this study is organized as follows. Section 2 discusses the categorization of perceptions towards Islamic banking. Section 3 provides literature review on the related work in this field. Section 4 provides criteria of Islamic bank selection from customers' perspective and Section 5 is the conclusion.

\section{Categorization of Perception towards Islamic Banking}

Previous studies on perceptions of Islamic banking customers can be categorized into four. The first category is studies on perception towards Islamic banking that have been conducted in either predominantly Muslim countries such as Pakistan or predominantly non-Muslim countries such as Singapore. The second group of studies has focused on Islamic banking customer in general without separating them by religious affiliations such as Muslims and non-Muslim. The third category is a comparative study on customers of Islamic and conventional banking. The final category which has relation to the present studies conducted on non-Muslim customers of Islamic banking.

These studies show that countries specifics have influences in the outcome of findings as people's worldview in particular country is shaped by legal, social, religious and economic setting. For example, respondents from predominantly Muslim countries such as Pakistan, Bangladesh and Bahrain indicate a better understanding of Islamic banking as compared to respondents from predominantly non-Muslim countries such as Singapore and United Kingdom (Hassan, 2007; Bley \& Kuehn, 2004; Khan et al., 2008; Metawa \& Al-Mossawi, 1998; Gerrard \& Cunningham, 1997; Rammal \& Zurbruegg, 2007).

A comparative study on customers of both Islamic and conventional banking moreover provides an indicator to examine the selection criteria of banking among non-Muslim customers (Ahmad \& Harun, 2002; Khan et al., 2008; Zainol \& Shaari, 2008; Haque et al., 2009). It is because previous studies indicated some reasons to be the same patronage factors among customers, but they were not consensus on which factor is more important than others.

\section{Literature Review}

Previous studies acted as an indicator to determine customers' perception towards Islamic banking. For instance, Hassan (2007) studied customers' perception towards Islamic banking in Pakistan. His study examined several 
important dimensions including knowledge, socio-religious context, Shari'ah compliances, willingness to deal with Islamic banks, and quality and attractiveness of offerings. This study found a positive perception of all dimensions investigated with customers indicating overall high satisfaction towards products and services of Islamic banks as compared to conventional banks.

Rashid, Hassan and Ahmad (2010) conducted a study on perception of customers towards domestic Islamic banks in Bangladesh. They examined six critical elements, namely corporate efficiency, compliance with Islamic rules, convenience, core banking, confidence, and cost benefit. This study found that customers are highly satisfied with corporate efficiency and compliance with Islamic rules as substantial factors for them to choose their intended service. In the case of Malaysia, Dusuki and Abdullah (2006) studied several critical reasons why Malaysian customers patronize Islamic banks and measured the elements of reputation, service delivery, product price, and social responsibility of Islamic banks. The study found that a combination of Islamic and financial reputation and service quality are the main patronage factors.

Specifically, among corporate customers, Ahmad and Harun (2002) conducted a study to examine their perception towards Islamic banking in Malaysia. They examined factors such as the usage of banking facilities, respondents' understanding of Islamic banking concept and practices, and personal opinions towards Islamic banking. They found that cost of the products and services is the most important factor perceived by corporate customers in selecting their banks. Similarly, Rustam et al. (2011) discussed three main parameters to determine the perception of corporate customers towards Islamic banking in Pakistan. They examined factors such as the usage of conventional and Islamic banking facilities, respondents' understanding of Islamic banking system, and their personal opinion on various aspects of Islamic banking products like economic and religious view. They found that the Islamic banking industry has good potential within the Pakistani corporate sector.

Instead of the Islamic banks' customers, few studies conducted to determine perception of bankers and students towards Islamic banking. For example, a research conducted by Zainol and Shaari (2008) on bankers' perception towards Islamic banking in both Islamic and conventional banks. In their study, they have included several critical factors, namely Islamic products and services, the training and experience, and the potential of Islamic banking in Malaysia. The result revealed that bankers in Islamic banks have more positive perceptions towards Islamic banking as compared to bankers in conventional banks.

Bley and Kuehn (2004) focused on students' knowledge and perception towards conventional and Islamic finance in United Arab Emirates (UAE). This study investigated the elements of financial knowledge, religion and language on self-reported attitudes and preferences for financial services and found that students' knowledge on conventional banking terms and concepts was higher than Islamic banking terminology. However, students with higher academic achievement showed a better response towards understanding Islamic banking concepts and practices.

Razak and Mohammed (2008) conducted a study on the acceptance of Muslim and non-Muslim customers on Islamic banking in Malaysia towards the features and operation of a specific product of Islamic banking, which is Bai Bithaman Ajil (BBA). This study found a high level of dissatisfaction among customers as evidenced by their low intention to use BBA, which the researchers then suggested, is replaced with Musyarakah Mutanakisah Partnership (MMP).

In case of retail banking, Thambiah et al. (2011) studied customers' perception and preference on Islamic Retail Banking (IRB). They examined the difference in terms of awareness, perception, and preferences on IRB between the urban and rural banking customers of Malaysia. The study found that there is a significant difference in terms of awareness and on perceived complexity, uncertainty, and observability. There also seem to be some variations for returns, loan repayment period, service charges, and overdraft facilities.

Comparing Muslims to non-Muslims, Loo (2010) conducted a study in Malaysia to gauge the different attitudes and perception towards Islamic banking. He examined the elements of knowledge, understanding of Islamic banking concepts, conflict with religious beliefs, together with the other elements of attractiveness of Islamic banking, disadvantages of Islamic banking, promotional influence, prospects of Islamic banking, and willingness to do business with Islamic banking. This study found that Muslims are supportive of Islamic banking while non-Muslims perceived Islamic banking as relevant mainly to Muslims.

A study conducted on the perception of non-Muslims towards Islamic banking by Mahamad and Tahir (2010) in Kuala Terengganu, examined the perception of users and non-users of Islamic banking from two elements, namely understanding of Islamic banking concept and practices, and bank selection criteria. They found low confidence among non-Muslims on the ability of Islamic banks to effectively compete with conventional banks, while non-users indicated a low willingness to deal with Islamic banks. This study also found that high return on 
investment is the most important criteria for banking selection among non-Muslims. In Kuala Lumpur, a recent study conducted by Abdullah, Sidek and Adnan (2012) on perception of non-Muslim customers towards Islamic banks in Malaysia revealed that Islamic banking services are making headway among non-Muslims in Kuala Lumpur, by observing the knowledge and understanding of Islamic banking among respondents, bank selection criteria, general perception of customers, among others.

\section{Selection Criteria for Islamic Banks from Customers' Perspective}

Different researchers have set different criteria for the measurement of customers' perception as reviewed in the literatures, whereby various studies have shown that several criteria normally influence customer perception towards their choices of banking. Thus, from a comprehensive literature review this study identified six common criteria for Islamic banks selection. These elements are the understanding of Islamic banking concepts, Shari'ah compliance, religious contradiction, quality and effectiveness of offerings, willingness to deal with Islamic banks, and prospect and potentials of Islamic banking.

\subsection{Understanding of Islamic Banking Concepts}

In predominantly non-Muslim countries, a study conducted by Gerrard and Cunningham (1997) in Singapore found there is no difference of understanding on Islamic banking concepts between Muslims and non-Muslims. They revealed that out of 190 respondents, a very low percentage of respondents understood basic Islamic banking terms. Only 6 percent of respondents knew about riba, while only 2 percent knew what Shari'ah is. Similarly, a study conducted by Rammal and Zurbruegg (2007) among Muslims in Australia found only 55.7 percent of respondents were aware of the existence of Islamic banking.

On the contrary, respondents from a country with predominantly Muslims showed a good understanding on Islamic banking influence Islamic banks selection. Metawa and Al-Mossawi (1998) conducted a study in Bahrain and found that $70 \%$ of respondents were aware about the existence of Islamic banking scheme. Kuehn and Bley (2004) studied the perception and knowledge of students towards Islamic banking in UAE. They tested hypotheses on lack of basic Islamic product knowledge, aspect of religion, and cultural differences to determine students' perception towards the Islamic financial system. Language barriers prevented students from learning the Islamic financial system, but students with good academic achievement showed a good understanding of Islamic banking concepts.

In Pakistan and Bangladesh, studies showed that people possessed a good understanding of Islamic banking concepts. Hassan (2007) conducted a research on understanding of Pakistanis towards Islamic banking and found $90 \%$ of respondents understood Islamic banking terms such as 'riba'. Similarly, Khan et al. (2008) found $92 \%$ of respondents in Bangladesh were aware with the existence of Mudarabah (profit sharing) saving account and $82 \%$ aware with the existence of Wadiah current account.

In Malaysia, Mahamad and Tahir (2010) conducted a study on the perception of non-Muslim towards Islamic banking in Kuala Terengganu and found that 54 percent of non-Muslim customers possess a moderate understanding of Islamic banking by which they were able to define correctly the meaning of Islamic banking. In an urban city of Malaysia, Kuala Lumpur, a study by Abdullah et al. (2012) revealed that non-Muslims at young age and with higher academic qualification possessed better knowledge and understanding of Islamic banking concepts.

Two studies conducted in Kuala Lumpur to examine people's understanding on Islamic banking without distinguishing between Muslims and non-Muslims. Hamid and Nordin (2001) conducted a study among bank customers in Kuala Lumpur and found that customers possessed very limited knowledge of Islamic banking. Even though 48 percent of the respondents claimed that there were familiar with the Islamic banking financial products, but only 15 percent were able to correctly describe the products once they were asked. Surprisingly, 60 percent of the respondents could not differentiate between Islamic banking products and conventional banking products. Similarly, a study conducted by Marimuthu et al. (2010) on the factors that determine acceptance of Islamic banking in Klang Valley found that among all of the 240 respondents, 57.6 percent indicated that they have limited knowledge on Islamic banking. Only 6.2 percent of respondents possessed good knowledge on the products and facilities offered by Islamic banks and 7.6 percent seemed to have some knowledge about the differences of Islamic banking products.

\subsection{Shari'ah Compliance}

Some studies have suggested that customers choose Islamic banks mainly on religious grounds. Thus, customers in Islamic banks seriously consider whether the bank complies with Shari'ah rules in all stages of banking activities (Haron et al., 1994; Metawa \& Al-Mossawi, 1998; Ahmad \& Haron, 2002; Khan, Hassan \& Shahid, 
2007). The variables deemed important under religious (Islamic) construct which include compliance to Shari'ah rules, offerings of Shari'ah compliant services, and offering interest free loans, among others.

Khan et al. (2007) conducted a study on banking behavior of Islamic bank customers in Bangladesh found that religious principles was the key bank selection criterion of the Islamic bank customers. They found that among all variables measured, only the element of religious principles showed an above-average preference among the customers. Similarly, Rashid and Hassan (2008) found compliance to Shari'ah law is one of influential factor for banking selection among customers in Bangladesh. This study thus supports the previous study by Metawa and Al-Mossawi (1998). According to Rashid and Hassan (2008) religious principles remain at the heart of people's preference for Islamic banks, which indicates that the banks should remain highly dedicated to Islamic principles.

However, in the case of Malaysia with the existence of multi religious society, the issue of Shari'ah compliance perceived to be important for Muslim customers, but not to non-Muslims, and it is closely relate to their understanding of Islamic banking itself. Razak and Mohammed (2008) conducted a research to examine the customers' acceptance on Islamic Home Financing (BBA) found high level of dissatisfaction among Muslim customers is due to inability of BBA to fulfill broad objectives of justice, equality and societal well being. Non-Muslim customers however seem to have greater beliefs in BBA and its ability to fulfill socially desirable objectives. This study however focused on specific product of Islamic banking which was Bai Bithaman Ajil, rather than to bring out the general issue of Shari'ah compliance of Islamic banking in general.

\subsection{Religious Contradiction}

Studies on religious issue as banking selection criteria showed different findings as it perceived to be the most important criteria especially among Muslims, while not to non-Muslims. Some studies showed religious issues as not to be the most important factor of banking selection. For example, Metawa and Al-Mosawwi (1998) found religion as the main factor for banking selection among respondents in Bahrain. It is supported by a study conducted by Bley and Kuehn (2004) among Muslims in UAE that the preference for Islamic banking was primarily driven by religious beliefs, not financial knowledge. That is, the stronger the religious commitment, the greater preference for Islamic banking services. Accordingly, Khan et al. (2008) also examined the criteria of banking selection among customers in Bangladesh found religion as the main factor attracted respondents to patronize Islamic banks. However, Naser et al., (1999) found that religious issue to be the second important factor of banking selection in Jordan. Similarly, when comparing Islamic and conventional bank customers in Jordon, Erol and El-Bdour (1989) found that profitability was the key motivation for the customers to deal with the banks. Religious motivation according to them was not a primary criterion.

Consequently, a study conducted by Dusuki and Abdullah (2007) in Malaysia found that religious factor is not the main criteria for banking selection. They found that competent and knowledgable personnels, followed by friendly personnel and service quality as their main patronage factors. However, Haque (2009) examined factors attracted 168 bank customers in Malaysia to deal with Islamic banks and found that religious perspective as one of the factors that positively influenced respondent in banking selection together with service quality, confidentiality, social perspective and variety of offerings.

In comparing between Muslims and non-Muslims in banking selection criteria, Loo (2010) found that Muslims were attracted to Islamic banking because of religion factor, while non-Muslims ranked religion as the last place out of five factors measured. On the other hand, among non-Muslims customers of Islamic bank in Kuala Lumpur, a study conducted by Abdullah et al. (2012) found the relationship between the religion with perception towards Islamic bank did exist.

In case of country with predominantly non-Muslims, a study conducted by Gerrard and Cunningham (1997) in Singapore found bank selection was not influence by religious factor when compared between Muslims and non-Muslims. For both Muslims and non-Muslims, profitable return on investment were the key motivator in choosing Islamic bank but not religion.

\subsection{Quality and Attractiveness of Offerings}

Although the religious dimension plays an important role in banking selection, quality and attractiveness of offerings is also perceived as significantly important for the customers to patronize Islamic banking. Since some previous research indicated that religion is no longer the main factor in attracting customers, Islamic banks should recognize that customers view them just like any other commercial bank (Haron et al., 1994). Thus the quality of service and the products and services offered must be comparable with those offered by the commercial banks. 
Mokhlis, Nik Mat and Salleh (2008) studied on the commercial bank selection among undergraduate students in Malaysia found the secure feelings as the most important factor to patronize bank, followed by ATM services, financial benefit, service provision, proximity and the branch location. Non-people influential, attractiveness and people influence considered to be not significant factors in influencing their decision in selecting bank. However, Kaynak and Whiteley (1999) stressed on interaction orientation such as fast and efficient service to be the major factor of customers' patronization.

In another study by Ahmed, Rehman and Safwan (2010) found service quality has significant influences on customer satisfaction in the case of Islamic and conventional banking, while the magnitude of effect is greater in Islamic banking as compared to conventional banking. Their study on the perception of satisfaction among bank customers with the existence of two banking systems in Pakistan found that customers of Islamic banks were more satisfied as compared to customers of conventional banks. A study conducted by Metawa and Almossawi (1998) on banking behavior of Islamic banking customers and found that most customers were highly satisfied with the products and services of Islamic banks. The researchers then suggested that bankers should develop professionalism and competency to maintain profitable relations with customers.

In Malaysia, a study conducted among commercial banks customers by Haron et al. (1994) found three critical factors that influence customers' bank selection. These factors are fast and efficient service, speed of transaction, and friendly bank personnel. Similarly, Dusuki and Abdullah (2006) determined the importance of service quality to attract more customers and they explained that Islamic banks can no longer depend on promoting the Islamic factor but also service quality. They ranked knowledgeable and competent personnel as the most important factor for banking selection criteria of Islamic bank, followed by friendly personnel, customer service quality, Islamic reputation and image, and Islamic reputation.

Among Muslim customers of Islamic bank, Rashid et al. (2008) found the higher demand of Islamic banking products and services requires existence of superior quality in service, beside the efficiency in system, strict compliance to Shari 'ah and satisfactory community service through job creation and ensuring consistency in service provisions. The study further demonstrated that faster transaction system, less cost of banking, and efficient counter management can add value to everyday volume of transactions and simultaneously increase customer satisfaction. Similarly, Erol and El-Bdour (1989) identified three key selection criteria perceived as important while selecting Islamic banks among Muslim customers were fast and efficient services, reputation and confidentiality.

Among corporate customers, Rustam et al. (2011) argued that majority of them perceived both religion and economics as the patronage factors in Islamic bank selection. This particular study showed that factors such as cost and benefit to the company, quality of service delivery, size and reputation of the bank, convenience, and friendliness of bank personnel were considered critical for bank selection.

In another study on determinants of bank selection showed that high return to deposit holders as the most important criteria of banking selection, followed by quality of service, availability of ATM machine, diversity of loan facilities, confidentiality, fast and efficient service and variety of products offered (Mahamad \& Tahir, 2010). On the contrary, a study conducted by Abdullah et al. (2012) showed the hesitancy of non-Muslim customers on the ability of Islamic banks to improve banking facilities and products, due to lack of information provided by the banking fraternity to the public.

In summary, previous studies show that the element of quality, confidentiality, reputation, speed of transaction, cost-benefit, consistency, competency and professionalism are considered critical factors on Islamic banks selection.

\subsection{Prospect and Potentials of Islamic banking}

Rashid et al. (2011) conducted a study on the prospect and growth potentials of Islamic banks in Bangladesh from both Islamic and conventional bankers' perspective. They found that conventional bankers believe that Islamic banks only claim but do not actually follow the true Shari'ah based system of banking. For them, the conventional system of banking is more lucrative and it stands as an honest method of banking as opposed to Islamic banking, which they feel is only profitable as a Strategic Business Unit (SBU). In contrast, Islamic bankers endorse the view of risk minimization by zero interest rate, while conventional banks do not reinforce this claim. However, Islamic bankers believed that Islamic banks in Bangladesh have a greater social and moral motive to fulfill, even at the expense of reduced profit.

In Malaysia, with the high prospect and potentials of Islamic banking as opined by some great scholars, there is a need to examine how non-Muslim customers perceived the prospect and potentials of Islamic banking. A study 
conducted by Loo (2010) found that non-Muslims viewed the prospect and potentials of Islamic banking as average, compared to Muslims who believed a strong prospect and potentials of Islamic banking in Malaysia. For non-Muslims, the Baby Boomers see the stronger prospect and potentials of Islamic banking compared to X-Generation.

A study on perception of non-Muslims towards Islamic banking in Kuala Terengganu conducted by Mahamad and Tahir (2010) found low acceptance among the non-Muslim community towards Islamic banking as an alternative over conventional banking. They found that Islamic banking was able to attract more non-Muslim customers if Islamic banks can fulfill their selection criteria of banking, which was quality of services provided. Meanwhile, a study by Abdullah et al. (2012) indicated most of the respondents believe that Islamic banking will dominate the banking industry in Malaysia in the near future. This is in line with the government vision for Malaysia to be an international hub for Islamic banking and finance by 2020 .

\subsection{Willingness to Deal with Islamic Banking}

In a country with predominantly non-Muslims such as Singapore, Gerrard and Cunningham (1997) conducted a study among both Muslim and non-Muslim respondents. This study found a low willingness of respondents to deal with Islamic bank with the majority of respondents regardless Muslims or non-Muslim would withdraw their deposits if no profit was distributed. This implies that customers give priority on attaining profit when they choose to put money in banks.

In contrast, for the countries with predominantly Muslims, findings showed strong willingness of customers to deal with Islamic banks. For example, a study conducted by Khan et al. (2007) on banking behavior of Islamic bank customers in Bangladesh. Interestingly, this study revealed that about 70 percent of the customers had previous relationship with conventional banks. Therefore, Khan's study indicated that Islamic banks have shown good progress in seizing customers from conventional banks and about half of the respondents have more than 4 years relationship with Islamic banks. Such a long tenure of relationship signifies the ability of customer retention by Islamic banks as well as the customers' loyalty to the banks' products and services.

In comparing between Muslims and non-Muslims' willingness to deal with Islamic banks in Malaysia, Loo (2010) found that Muslims were supportive to Islamic banking, while non-Muslims viewed Islamic banking as relevant primarily only to Muslims. However, among non-Muslims, X-Generation has a more favorable perception towards Islamic banking than Baby Boomers.

Another two studies conducted in Malaysia which includes commercial and corporate bank customers. Haron et al. (1994) conducted a study among commercial bank customers in Alor Setar, Sungai Petani and Kangar. Primary this study examined customers' understanding on Islamic banking concepts. The study found that 99 percent of Muslim while 70 per cent of the non-Muslim respondents were aware about the existence of the Islamic bank, while 12 percent of Muslims and 32 percent non-Muslims believed that the Islamic banking was relevant primarily to Muslims. This study also revealed the willingness of non-Muslims to establish a relationship with Islamic banks if they have a complete understanding about Islamic banking concepts. A study conducted by Ahmad and Haron (2002) on perceptions of Malaysian corporate customers towards Islamic banking surveyed 45 respondents comprising 20 percent Muslims and 80 percent non-Muslims. The finding however showed that Islamic banking products were not popular among corporate customers.

\section{Conclusion}

From a comprehensive review of literature, it is realized that it is very important to examine customers' perception towards Islamic banking selection criteria. This is because, over the year, the trend, characteristics and preferences would be change as the banking industry is dynamic in nature, which could lead to different significant result. According to Holliday (1996), the importance of understanding customers' perception in bank selection has become an enduring research agenda in banking. In order to penetrate and operate side by side with conventional banks, Islamic banks must be able to understand the people's perceptions that their system is much better than the conventional system. Hence, owing to the highly competitive environment, Islamic banks need to study customer perceptions in bank selection to help them market their products effectively (Haron, Ahmad \& Planisek, 1994; Dusuki \& Abdullah, 2006). According to Rustam, Bibi, Zaman, Rustam and Zhid-ul-haq (2011). To summarise, a new conceptual model for Islamic banks selection criteria should include understanding of Islamic banking concept, Shari'ah compliance, religious contradiction, quality and attractiveness of offerings, prospect and potentials of Islamic banking, and willingness to deal with Islamic banks.

\section{References}

Abdullah, A. A., Sidek, R., \& Adnan, A. A. (2012). Perception of Non-Muslim Customers Towards Islamic 
Banks in Malaysia. International Journal of Business and Social Science, 3(11).

Ahmad, N., \& Haron, S. (2002). Perceptions of Malaysian Corporate Customers towards Islamic Banking Products \& Services. International Journal Of Islamic Financial Services, 3(4).

Ahmed, A., Rehman, K., \& Saif, M. I. (2010). Islamic Banking Experience of Pakistan: Comparison of Islamic \& Conventional Banks. International Journal of Business Management, 5(2), 137-144.

Aziz, Z. A. (2006). Islamic Banking and Finance Progress and Prospects: Collected Speeches 2000-2006. Bank Negara Malaysia, Kuala Lumpur.

Bley, J., \& Kuehn, K. (2004). Conventional versus Islamic Finance: Student Knowledge and Perception in the United Arab Emirates. International Journal of Islamic Financial Services, 5(4).

Chew, E. (2011, October 7). Malaysian Islamic Banking Assets Rise 15 Percent to \$123 Billion. Bloomberg Business Week. Retrieved February 2012 from http: //www.businessweek.com/news

Dusuki, A. W., \& Abdullah, N. I. (2007). Why do Malaysian Customers Patronize Islamic Banks? International Journal of Bank Marketing, 25(3), 143-160. http://dx.doi.org/10.1108/02652320710739850

Erol, C., \& El-Bdour, R. (1989). Attitude, Behavior and Patronage Factors of Bank Customers towards Islamic $\begin{array}{lllll}\text { Banks. International Journal of Bank } & \text { Marketing, }\end{array}$ http://dx.doi.org/10.1108/02652328910132060

Gerrard, P., \& Cunningham, J. B. (1997). Islamic banking: A study in Singapore. International Journal of Bank Marketing, 15(6), 204-216. http://dx.doi.org/10.1108/02652329710184433

Haque, A., Osman, J., \& Ismail, A. Z. (2009). Factor Influences Selection of Islamic Banking: A Study on Malaysian Customer Preferences. American Journal of Applied Sciences, 6(5), 922-928. http://dx.doi.org/10.3844/ajassp.2009.922.928

Haron, S., Ahmad, N., \& Planisek, S. L. (1994). Bank Patronage Factors of Muslim and Non-Muslim Customers. International Journal of Bank Marketing, 12(1), 22-40. http://dx.doi.org/10.1108/02652329410049599

Hassan, M. (2007). People's Perceptions towards Islamic Banking. A Fieldwork Study on Bank Account Holders' Behaviour in Pakistan, 153-176.

Holliday, K. (1996). Keeping close to the customer. Bank Marketing, 28(6), 14-19.

Husin, A. S. (2008). Crossing over: Islamic Banking Needs To Reach Out to New Customers. Retrieved January 15, 2012 from http://www.gtnews.com

Kaynak, E., \& Whiteley, A. (1999). Retail Bank Marketing in Western Australia. International Journal of Bank Marketing, 17(5), 221-233. http://dx.doi.org/10.1108/02652329910292693

Khan, M. S. N., Hassan, M. K., \& Shahid, A. I. (n.d). Banking Behaviour of Islamic Bank Customers in Bangladesh. Journal of Islamic Economics, Banking and Finance.

Lists of Licensed Banking Institution in Malaysia. Retrieved February 24, 2012 from http://www.bnm.gov.my/index.php?ch=li\&cat $=$ islamic\&type $=I B \&$ fund $=0 \& c u=0$

Loo, M. (2010). Attitudes and perceptions towards Islamic Banking among Muslims and non-Muslims in Malaysia: Implications for Marketing to Baby Boomers and X-Generation. International Journal of Arts and Sciences, Concordia University College of Alberta, Canada.

Mahamad, M., \& Tahir, I. M. (2011). Perception of Non-Muslims towards Islamic Banking: A Pilot Study. Journal of Humanitarian, 16.

Malaysia's Value Propositions \& Pioneering Achievements. Retrieved April 7, 2012 from http://www.mifc.com

Marimuthu, M., Jing, C. W., Gie, L. P., Mun, L. P., \& Ping, T. Y. (2010). Islamic Banking: Selection Criteria and Implication. Global Journal of Human Social Science, 10(4) (Ver 1.0).

Metawa, A. S., \& Al-Mossawi, M. (1998). Banking Behavior of Islamic Bank Customers: Perspectives and Implications. International Journal of Bank Marketing, 16(7), 299-313. http://dx.doi.org/10.1108/02652329810246028

Mokhlis, S., Nik Mat, N. H., \& Salleh, H. S. (2008). Commercial Bank Selection: The Case of Undergraduate Students in Malaysia. International Review of Business Research Papers, 4(5), 258-270.

Naser, K., Jamal, A., \& Al-Khatib, K. (1999). Islamic Banking: A Study of Customer Satisfaction and Preferences in Jordan. International Journal of Bank Marketing, 17(3), 135-151. 
http://dx.doi.org/10.1108/02652329910269275

Pollard, J., \& Samers, M. (2007). Islamic Banking and Finance: Postcolonial Political Economy and The Decentring of Economic Geography. Trans Inst Br Geogr NS 32 313-330 2007, 313-330. http://dx.doi.org/10.1111/j.1475-5661.2007.00255.x

Rammal, H. G., \& Zurbruegg, R. (2007). Awareness Of Islamic Banking Products Among Muslims: The Case Of $\begin{array}{lllll}\text { Australia. Journal of Financial Services Marketing, } & \text { 12(1), 65-74. }\end{array}$ http://dx.doi.org/10.1057/palgrave.fsm.4760060

Rashid, M., Hassan, M. K., \& Ahmad, A. (2008). Quality Perception of the Customers towards Domestic Islamic Banks in Bangladesh, Journal of Islamic Economics, Banking and Finance, 5, 110-131.

Razak, D. A., \& Mohammed, M. O. (2008). Consumers' Acceptance on Islamic Home Financing: Empirical Evidence on Bai Bithaman Ajil (BBA) in Malaysia. IIUM International Accounting Conference IV (INTAV).

Rosly, A., \& Abu Bakar, M. A. (2003). Performance of Islamic and Mainstream Banks in Malaysia. $\begin{array}{lllll}\text { Informational Journal of Social } & \text { Economics, } & 30(12), & 1249-1265 .\end{array}$ http://dx.doi.org/10.1108/03068290310500652

Rustam, S., Bibi, S., Zaman, K., Rusram, A., \& Zahid-ul-Haq. (2011). Perceptions of Corporate Customers Towards Islamic Banking Products and Services in Pakistan. The Romanian Economic Journal, XIV(41).

Shanmugam, B., Perumal, V., \& Ridzwa, H. A. (2004). Islamic Banking: An International Perspective. Serdang: University Putra Malaysia Press.

Siddiqi, M. N. (1988). Islamic Banking: Theory and Practice. In Mohammad Ariff (Ed.), Banking In Southeast Asia, Singapore: Institute Of Southeast Asian Studies (pp. 34-67).

Thambiah, S., Eze, U. C., Santhapparaj, A. J., \& Arumugam, K. (2011). Customers' Perception on Islamic Retail Banking: A Comparative Analysis between the Urban and Rural Regions of Malaysia. International Journal of Business and Management, 6(1).

Zainol, Z., Shaari, R., \& Muhamad Ali, H. (2008). A comparative analysis of Bankers' Perceptions on Islamic Banking. International Journal of Business Management, 157-168. 